\title{
Penyelesaian Sengketa Tanah Masyarakat Adat Karuhun Urang (AKUR) Di Desa Cigugur Kuningan Melalui Lembaga Peradilan
}

\author{
Agung Basuki Prasetyo \\ Fakultas Hukum Universitas Diponegoro \\ JL. Prof. Sudharto No. 1 Semarang, Jawa Tengah, 50275 \\ agungbasukiprasetyo@gmail.com
}

\begin{abstract}
ABSTRAC
Dispute resolution through judicial institutions on land in the Karuhun Urang (AKUR) Indigenous Community of Cigugur Village, Kuningan Regency has won the Plaintiffs based on inheritance law, while land according to the AKUR customary law cannot be inherited. Such rights in the legislation are referred to as communal rights. This writing is about fulfilling the principle of justice in the court ruling. The judgment of the judge in his decision considers the object of the dispute as inheritance, and does not consider the testimony of witnesses who are not sworn, because the religion column in the KTP is empty. So that the Plaintiff wins. The judge based his legal considerations more on the Positivism paradigm, which is based solely on written rules such as in legislation, by putting aside the values that live in society.

Based on the structural, cultural and substantive components identified there is no principle of justice for the AKUR Community. There are philosophical, historical, and socio-cultural reasons for defending disputed objects for the preservation of AKUR Community customs.
\end{abstract}

Keywords: land disputes, indigenous peoples, customary rights.

\begin{abstract}
ABSTRAK
Penyelesaian sengketa melalui lembaga peradilan terhadap tanah yang berada di lingkungan Masyarakat Adat Karuhun Urang (AKUR) Desa Cigugur, Kabupaten Kuningan telah memenangkan pihak Penggugat berdasarkan pada hukum waris, sedangkan tanah menurut hukum adat Masyarakat AKUR tidak dapat diwariskan. Hak semacam itu dalam Peraturan Perundang-undangan disebut dengan hak ulayat. Penulisan ini mengenai pemenuhan asas keadilan dalam putusan peradilan tersebut. Pertimbangan hakim dalam putusannya menganggap objek sengketa sebagai harta warisan, dan tidak mempertimbangkan keterangan saksi yang tidak disumpah, karena kolom agama di KTP kosong. Sehingga Penggugat menang. Hakim lebih mendasarkan pertimbangan hukumnya pada paradigma Positivisme, yang hanya dilandasi aturan tertulis seperti dalam perundangundangan, dengan mengesampingkan nilai-nilai yang hidup dalam masyarakat.

Berdasarkan komponen struktural, kultural, dan substantif teridentifikasi tidak terdapat asas keadilan bagi Masyarakat AKUR. Terdapat alasan filosofis, historis, dan sosial budaya dalam mempertahankan objek sengketa guna pelestarian adat istiadat Masyarakat AKUR.
\end{abstract}

Kata Kunci: sengketa tanah, masyarakat adat, hak ulayat. 


\section{PENDAHULUAN}

Bangsa Indonesia memiliki keragaman sistem hukum. Selain berlaku pranata hukum negara (state law), secara de facto juga berlaku pranata hukum adat, dan pranata hukum agama (religious law) dalam komunitas-komunitas keagamaan, dan mekanisme-mekanisme regulasi sendiri (inner-order mechanism atau self-regulation) dalam kehidupan kelompok masyarakat. $^{1}$

Masyarakat Hukum Adat menggunakan pranata hukum adat dalam menjalankan kehidupan sehari-harinya. Keberadaan Masyarakat Hukum Adat (MHA), sebagai pihak yang tunduk kepada hukum adat yang keberadaannya diakui dalam pasal 18B ayat (2) dan pasal 28 I ayat (3) UUD NRI 1945.

MHA memiliki hak-hak yang seharusnya dilindungi oleh negara, salah satunya adalah hak ulayat. Antara MHA dengan tanah memiliki hubungan yang disebut sebagai hubungan religus magis yang menyebabkan mereka memperoleh hak untuk menguasai dan memanfaatkan wilayahnya, seperti memungut hasil tanaman yang hidup di atas tanahnya, serta berburu binatang yang hidup di wilayahnya. ${ }^{2}$

Pengakuan hak ulayat MHA terdapat dalam Pasal 3 UUPA, yakni dengan syarat, sepanjang kenyataannya masih ada, harus sesuai dengan kepentingan nasional, dan tidak boleh bertentangan dengan peraturan perundang-undangan yang lebih tinggi. Namun ternyata apa yang telah dijamin dan dijanjikan mengenai keberadaan masyarakat hukum adat ini seolah dilupakan dan hak-haknya diabaikan. ${ }^{3}$

Pengabaian ini menimbulkan konflik persengketaan tanah ulayat baik yang bersifat vertikal maupun horizontal. Data Konsorsium Agraria menyebutkan ada sekitar 659 konflik di berbagai wilayah Indonesia terkait tanah ulayat pada tahun $2017 .{ }^{4}$ Salah satu konflik bersifat horizontal yang akan dibahas adalah mengenai konflik yang berkaitan dengan tanah Masyarakat Adat Karuhun Urang (Masyarakat AKUR). Konflik ini sempat merebak ke publik

\footnotetext{
${ }^{1}$ I Nyoman Nurjaya dalam Sukirno, Politik Pengakuan Hak Ulayat, Jakarta, Prenadamedia Group, 2018, hal. v.

${ }^{2}$ Agung Basuki Prasetyo, Hak Ulayat Sebagai Hak Konstitusional (Suatu Kajian Yuridis Empiris), MMH Jilid 39 No.2, Juni 2010, hal. 149.

${ }^{3}$ Berdayakan Masyarakat Adat, Lindungi Hak-haknya, Buletin, Gaung AMAN, Suara Masyarakat Adat, edisi Oktober-Desember 2017, hal. 24.

${ }^{4}$ Lusia Arumningtyas, Pengakuan Hutan Adat Minim, Perlu Terobosan pada 2018, diakses dari https://www.mongabay.co.id/2018/01/08/pengakuan-hutan-adat-minim-perlu-terobosan-pada-2018/ pada tanggal 15 Januari 2019.
} 
Vol 2, No. (2019): Law, Development \& Justice Review, Mei 2019. e-ISSN: 2655-1942

pada tahun 2017 karena terjadi aksi tidur di jalan menuju tempat objek eksekusi sebagai tanda penolakan atas eksekusi yang didasarkan pada putusan hakim yang sudah inkract.

Di Kabupaten Kuningan, Jawa Barat tepatnya di Desa Cigugur terdapat suatu MHA yang dikenal dengan nama Masyarakat Adat Karuhun Urang (AKUR) yang memiliki aliran kepercayaan bernama Sunda Wiwitan. Pada tahun 2009 diajukan gugatan oleh salah satu ahli waris bernama Djaka Rumantaka (masih keturunan pendiri Masyarakat AKUR) yang menuntut bahwa tanah tersebut merupakan bagian waris miliknya dari Ibunya, Ratu Djenar Alibassa. Objek sengketa merupakan tanah dan bangunan di Blok Mayasih RT/RW 29/10 Desa Cigugur, Kabupaten Kuningan yang ditinggali oleh E.Kusnadi yang dikenal sebagai abdi dalem sekaligus seniman masyarakat AKUR.

Sengketa ini kemudian sudah mendapatkan putusan inkracht sampai pada proses PK tahun 2014 yang memenangkan ahli waris sebagai pemegang hak atas tanah tersebut yang seharusnya. Namun proses eksekusi yang terjadi pada tahun 2017 kemudian dibatalkan karena adanya penolakan dari Masyarakat AKUR berupa aksi tidur di sepanjang jalanan menuju lokasi sehingga menghambat proses eksekusi yang akan dilakukan.

Putusan pengadilan dari tingkat pertama sampai dengan tingkat peninjauan kembali, seharusnya telah mempunyai kepastian hukum yang tetap, dengan memenangkan pihak Penggugat. Namun kenyataannya pelaksanaan putusan tersebut belum dapat dilakukan eksekusi sampai saat ini karena adamya penolakan dari pihak yang dikalahkan, yaitu Masyarakat AKUR. Mereka bersikukuh bahwa tanah sengketa tersebut merupakan tanah milik bersama yang tidak dapat dibagi waris, maka tidak seharusnya tanah sengketa dimenangkan oleh Penggugat.

Berdasarkan uraian di atas maka dapat dirumuskan masalah mengenai, Apakah putusan lembaga peradilan umum telah memenuhi asas keadilan bagi Masyarakat Adat Karuhun Urang di Desa Cigugur, Kabupaten Kuningan?.

\section{PEMBAHASAN}

\section{Deskripsi Masyarakat Adat Karuhun Urang (AKUR)}

Kesatuan Masyarakat AKUR adalah masyarakat adat telah ada sejak sebelum kemerdekaan Indonesia, yang dibentuk oleh Pangeran Sadewa Madrais Alibassa Kusumah 
Wijaya Ningrat atau yang biasa dikenal dengan nama Pangeran Madrais sebagai pewaris Kerajaan Gebang di Losari, Jawa Barat. Pada tahun 1802 Kerajaan Gebang dihancurkan oleh Belanda karena tidak mau bersekutu dengan Pemerintah Belanda, dan sering melakukan pemberontakan.

Pangeran Madrais di Desa Cigugur Kabupaten Kuningan menyebarkan ajaran kepercayaan tentang rasa kesadaran kemanusiaan dan rasa kesadaran untuk kebangsaan yang didasari Tri Tangtu yaitu rasa, budi dan pikir manusia. Ajaran Pangeran Madrais ini dikenal dengan nama Agama Djawa Sunda (ADS). Pengikut ADS dipercaya pernah mencapai puluhan ribu.

Melihat keadaan yang seperti itu kemudian Belanda khawatir ajaran ADS dapat membangkitkan semangat nasionalisme Indonesia. Pada tahun 1901 - 1908 Pangeran Madrais dibuang ke Tanah Merah di Digul, Merauke, Papua, karena sebagai pemberontak.

Pada awal kemerdekaan Indonesia, ajaran ADS terdaftar dalam Badan Kongres Kebatinan Indonesia (BKKI). Namun karena situasi politik nasional, organisasi ADS membubarkan diri tahun 1964. Meskipun begitu, nyatanya penganut ADS masih menjalankan tradisi leluhurnya. ${ }^{5}$

Tahun 1981 komunitas adat ini diinventarisir pada Kementerian Pendidikan dan Kebudayaan dengan nama Paguyuban Adat Cara Karuhun Urang (PACKU). PACKU kemudian dibubarkan dan para pengikutnya berlindung ke agama-agama tertentu, kebanyakan masuk kedalam agama Katolik. Larangan pendirian PACKU didukung dengan adanya Surat Keputusan Kepala Kejaksaan Tinggi Jawa Barat Nomor Kep.4/K.2.3/8/82. Sebagai akibat larangan tersebut, secara hukum status sekitar 2000 orang penganut PACKU tersebut menjadi ilegal dan secara politik menjadi tidak benar. ${ }^{6}$ Ahirnya pada tahun 1996 setelah dibebaskan untuk memeluk kepercayaan lagi, mereka kembali memeluk kepercayaan Sunda Wiwitan sampai dengan saat ini. ${ }^{7}$

Konsep ajaran Sunda Wiwitan dikenal dengan nama Pikukuh Tilu. yang menekankan kesadaran tinggi kodrat manusia (cara ciri manusia), kodrat kebangsaan (cara ciri bangsa), dan mengabdi kepada yang seharusnya (madep ka ratu raja). ${ }^{8}$

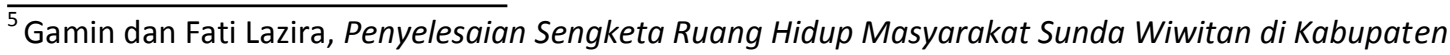
Kuningan, Jurnal Sosiologi Pendidikan Humanis Vol.2 No.1, Juli 2017, hal. 3.

${ }^{6}$ Roro Sri Rejeki, Agama Djawa Sunda (ADS), Religious, Jurnal Agama dan Lintas Budaya, Maret 2017, hal. 106.

${ }^{7}$ Roro Sri Rejeki, Loc. cit.

8 Ibid, hal. 95.
} 
Vol 2, No. (2019): Law, Development \& Justice Review, Mei 2019. e-ISSN: 2655-1942

Keberadaan Masyarakat AKUR tidak hanya bertempat di Desa Cigugur saja, namun menyebar di daerah Parahyangan seperti Bandung, Garut, Ciamis, Tasik, Subang, Karawang, dan Banjar, yang biasa berkumpul sebulan sekali di Paseban Tri Panca Tunggal, Desa Cigugur, Kuningan. Masyarakat AKUR dipimpin oleh seorang Pupuhu Adat. Masyarakat AKUR memiliki sebuah organisasi sosial yang berbasis kepada struktur patrilineal, artinya kekuasaan tertinggi berada pada keturunan laki-laki.

\section{Kasus Posisi Sengketa Tanah Masyarakat AKUR}

Penggugat adalah Rd. Djaka Rumantaka. Beliau merupakan cicit dari P. Madrais, cucu dari P. Tedjabuana, dan keponakan dari Ketua Adat Masyarakat AKUR saat itu yaitu P. Djatikusuma.

Pihak Tergugat I yaitu E. Kusnadi, selaku pihak yang menempati objek sengketa. Beliau merupakan anak dari Sumadihardja dan tidak ada hubungan keluarga dengan P. Tedjabuana. Tergugat II yaitu K.Mimin, selaku istri E. Kusnadi yaitu pihak yang menempati objek segketa

Tanah dan bangunan objek sengketa seluas $224 \mathrm{~m}^{2}$ yang secara administratif terletak di Blok Mayasih RT. 29/10, Kelurahan Cigugur, Kecamatan Cigugur, Kabupaten Kuningan yang tercatat dalam Buku Letter C No. 2321 persil 78a kelas D.1 dari jumlah keseluruhan Letter $\mathrm{C}$ tersebut seluas $6210 \mathrm{~m}^{2}$ atas nama Tedjabuana.

\section{Dasar Pertimbangan Hakim dalam Memutus Sengketa Tanah Masyarakat AKUR}

Beberapa Anggota Masyarakat Adat Nusantara (AMAN) menjelaskaan, pada pokoknya sengketa tanah Masyarakat AKUR tersebut ada ketidaksinambungan antar para pihak yang berperkara, sebab adanya perberbedaan pendekatan. Pihak Penggugat menggunakan pendekatan waris dan Para Tergugat menggunakan pendekatan adat.

Di dalam surat gugatannya, Penggugat memohon agar hakim dapat menetapkan Para Tergugat telah melakukan perbuatan melawan hukum (onrecht magendaag) yang tercantum dalam Pasal 1365 KUH Perdata karena Para Tergugat telah menempati objek yang seharusnya menjadi bagian waris dari Penggugat dan hakim mengabulkan gugatannya tersebut.

Berkaitan dengan dikabulkanya Penggugat oleh Hakim yang menganggap objek sengketa tanah tersebut merupakan objek Waris.

Salah satu pertimbangan hukum pada Pokok Perkara dalam Putusan PN Kuningan No. 7/Pdt.G/2009/PN.Kng tertulis bahwa ada bukti Surat Pernyataan Murkanda tertanggal 20 
Vol 2, No. (2019): Law, Development \& Justice Review, Mei 2019. e-ISSN: 2655-1942

November 2008 yang menerangkan bahwa pada hari Minggu, tanggal 17 Mei 1970 ketika Murkanda masih menjabat sebagai Kepala Kampung di Desa Cigugur, P. Tedjabuana memberikan pesan atau mandat agar memberikan beberapa bidang tanah kepada putriputrinya, termasuk tanah yang menjadi objek sengketa tersebut kepada putri kedua yaitu Ratu Dewi Alibassa yang ditandatangani oleh Murkanda sendiri diatas materai dan diketahui Kepala Kelurahan Cigugur Utari. Berdasarkan Surat Pernyataan tesebut hakim membenarkan bahwa P. Tedjabuana telah memberikan objek sengketa kepada anaknya yaitu Ratu Siti Djenar.

Analisis dan argumentasi dari hakim yang dituangkan pada pertimbangan hukum dalam Putusan PN Kuningan a quo dapat dipahami bahwa hakim hanya memandang sengketa ini murni sebagai sengketa waris. Para hakim berkesimpulan bahwa ketika Penggugat sudah memiliki alat bukti berupa Surat Tanda Pendaftaran Sementara Tanah Milik Indonesia atau Letter C atas nama Ratu Siti Djenar Alibassa No. C. 2321 Persil 78a Kelas d.1 tertangggal 20 November 2008 maka dengan begitu dapat disebut sebagai milik Ratu Siti Djenar dan sah sebagai harta warisan yang dapat dibagikan kepada para ahli waris yang berhak. Perlu digaris bawahi juga bahwa dibuatnya Letter $\mathrm{C}$ a quo ini didasari oleh Surat Pernyataan Murkanda, seorang Mantan Kepala Kampung di Cigugur, yang dibuat tanggal 20 November 2008 yang ditandatangani oleh dirinya sendiri.

Menurut Sudikno, alat bukti tertulis atau surat ialah segala sesuatu yang memuat tanda-tanda bacaan yang dimaksudkan untuk mencurahkan isi hati atau untuk menyampaikan buah pikiran seseorang dan dipergunakan sebagai pembuktia. ${ }^{9}$

Bukti kepemilikan tanah di Indonesia yang kuat adalah Sertipikat. Hal ini diatur pada Pasal 32 PP No. 24 Tahun 1997 tentang Pendaftaran Tanah yang memberikan definisi Sertipikat yaitu surat tanda bukti hak yang berlaku sebagai alat pembuktian yang kuat mengenai data fisik dan data yuridis yang termuat di dalamnya. Sertipikat Hak atas Tanah diterbitkan oleh Kantor Pertanahan. Masalahnya tidak semua tanah di Indonesia sudah didaftarkan, masih banyak tanah-tanah yang belum memiliki tanda bukti berupa Letter $\mathrm{C}$, yang hanya dicatatat oleh Kepala Desa.

Penjelasan mengenai alat bukti surat atau tulisan ini menegaskan bahwasannya Letter C a quo dan Surat Pernyataan Murkanda bukan merupakan sebuah akta atau Sertipikat yang

\footnotetext{
${ }^{9}$ Sudikno Mertokusumo dalam Sunarto, Peran Aktif Hakim dalam Perkara Perdata, Jakarta, Prenadamedia Grup, 2014, hal. 169.
} 
Vol 2, No. (2019): Law, Development \& Justice Review, Mei 2019. e-ISSN: 2655-1942

memiliki kekuatan pembuktian sempurna, melainkan hanya sebuah alat bukti berupa surat atau catatan yang ditulis seorang Kepala Desa atau seorang mantan Kepala Kampung di Cigugur, maka bisa saja keberadaannya dibantah oleh pihak Tergugat.

Para Tergugat dalam jawabannya mempertanyakan mengenai penyebab tidak diumumkannya pesan dari P. Tedjabuana untuk memberikan objek sengketa kepada Ratu Siti Djenar di tanggal 17 Mei 1970 jika memang sudah diamanatkan oleh beliau. Amanat tersebut justru baru pada tanggal 20 November 2008 dituangkan pada Surat Pernyataan Murkanda. Bukankah ini merupakan hal yang aneh dan ganjil karena dari tahun 1970 sampai dengan 2008 tidak ada masalah apa-apa, lalu tiba-tiba muncul surat gugatan kepada Para Tergugat yang menyebutkan bahwa mereka telah melakukan perbuatan melawan hukum karena telah menempati objek sengketa tersebut.

Para Tergugat mengajukan pula beberapa bukti kepada hakim. Bukti pertama yaitu dijelaskan pada halaman Putusan PN Kuningan a quo yang menyebutkan ada bukti Surat Bukti Pernyataan Pangeran Djatikusuma tanggal 13 Desember 2009 yang pada pokoknya membantah secara tegas Surat Pernyataan Murkanda dan Kutipan Sementara Buku Pendaftaran C Persil a quo. Surat pernyataan ini kemudian ditolak sebagai alat bukti sebagaimana tertulis pada pertimbangan hukum Putusan PN Kuningan a quo menyatakan bahwa surat tersebut hanya pernyataan pribadi dari P. Djatikusuma tanpa didukung oleh bukti lainnya, oleh karenanya belum dapat dijadikan bukti yang mendukung dalil sangkalan Para Tergugat. Ada juga tambahan yang diajukan pada memori kasasi halaman 17 yaitu adanya Surat Keterangan No. 100/49/Pem tertanggal 25 Januari 2010 tertanda Kepala Kelurahan Cigugur, Kabupaten Kuningan yang menerangkan bahwa Letter $\mathrm{C}$ a quo atas nama Ratu Siti Djenar tidak ada arsipnya di keluarahan. Namun mengenai bukti ini pula tidak dijadikan pertimbangan hakim.

Berdasarkan perbantahan yang dituliskan dan diajukan oleh Para Tergugat di pengadilan tersebut juga bukan merupakan alat bukti yang kuat karena hanya merupakan sebuah surat atau tulisan dari pendapat pribadi seseorang saja. Namun sangat disayangkan ketika bukti-bukti yang diajukan Para Penggugat dan langsung dikatakan tidak dapat diterima tetapi terhadap bukti utama yang diajukan oleh Penggugat, hakim tidak berupaya untuk mengecek keabsahan dan kebenaran bukti tulisan yang diajukan Penggugat.

Berkaitan keterangan saksi yang tidak disumpah, yakni keterangan saksi hidup Pangeran Djatikusuma sebagai anak dari Pangeran Tedjabuana tidak dapat dipertimbangkan 
dan tidak dapat dijadikan bukti yang mendukung dalil-dalil sangkalan Para Tergugat karena tidak dibawah sumpah.

Di persidangan, seorang saksi yang hendak memberikan keterangannnya terlebih dahulu akan disumpah di hadapan Majelis Hakim. Pada pasal 147 HIR mengenai Sumpah Saksi tertulis bahwa "Jika tidak ada permintaan pengunduran diri atau permintaan pengunduran diri dinyatakan tidak berasalan, maka sebelum saksi memberikan keterangannya, ia terlebih dahulu disumpah menurut agamanya." Komentar Moh. Djais dan Koosmargono mengenai pasal tersebut yaitu sumpah saksi diperlukan agar keterangan yang diberikan mempunyai kekuatan pembuktian karena menurut Pasal 303 HIR keterangan saksi yang tidak disumpah tidak mempunyai kekuatan pembuktian. Sumpah yang dilakukan menurut agamanya berarti maksudnya menurut agama yang dianut. Jika seseorang tidak beragama atau agamanya melarang untuk mengangkat sumpah, maka sumpah dapat diganti dengan janji yang mempunyai kekuatan dan akibat hukum seperti sumpah. ${ }^{10}$

Di dalam putusan PN Kuningan a quo hanya menuliskan bahwa saksi Pangeran Djatikusuma tidak di sumpah, tidak menerangkan bahwa sebagaimana pendapat Moh. Djais dan Koosmardjono bahwa sumpah dapat diganti dengan janji.

Pangeran Djatikusuma adalah saksi kunci, karena satu-satunya saksi hidup. Namun keterangannya hanya sekadar didengar saja dan tidak memiliki kekuatan hukum. Hakim beralasan karena kolom agama pada KTP, kosong.

Berdasarkan dasar pertimbangan-pertimbangan hukum bagi hakim dalam memutus sengketa tersebut dapat diidentifikasikan bahwa hakim menganut paradigma atau pendekatan positivisme. Paradigma ini memahami hukum sebagai produk eksplisit suatu sumber kekuasaan politik tertentu yang terwujud dalam sebuah peraturan perundangundangan yang berlaku secara nasional di suatu negara. ${ }^{11}$ Sama halnya dengan pertimbangan hukum ini karena hanya dilandasi pada aturan dan teks-teks normatif seperti dalam peraturan perundang-undangan, juga ada pemisahan unsur-unsur diluar hukum dengan hukum, artinya unsur-unsur seperti sosial, budaya, ekonomi tidak akan

\footnotetext{
${ }^{10}$ Mohammad Djais dan Koosmargono, Membaca dan Mengerti HIR, Semarang, Badan Penerbit Universitas Diponegoro, 2011, hal. 130.

${ }^{11}$ Erlyn Indarti, Diskresi dan Paradigma Sebuah Telaah Filsafat Hukum, (Pidato pengukuhan disampaikan pada upacara penerimaan jabatan Guru Besar dalam Filsafat Hukum pada Fakultas Hukum Universitas Diponegoro tanggal 4 November 2010), hal. 21.
} 
Vol 2, No. (2019): Law, Development \& Justice Review, Mei 2019. e-ISSN: 2655-1942

dipertimbangkan dalam memutus perkaranya. Sebagai konsekuensinya hakim akan mengabaikan asas persamaan dihadapan hukum dan melupakan asas keadilan.

\section{PUTUSAN LEMBAGA PERADILAN FORMAL SEHARUSNYA MEMENUHI ASAS KEADILAN.}

Semua amar putusan peradilan sampat tingkat Peninjauan Kembali, menguatkan putusan yang ada di PN Kuningan yaitu menyatakan dan menetapkan bahwa Penggugat merupakan orang yang berhak atas tanah tersebut dan menyatakan bahwa Para Tergugat telah melakukan Perbuatan Melawan Hukum.

Berdasarkan amar putusan peradilan maka terbit perintah bahwa objek sengketa harus dieksekusi. Tahun 2017 lalu tepatnya pada tanggal 24 Agustus 2017, ketika objek sengketa akan dieksekusi ada penolakan dari pihak Masyarakat AKUR yang ditandai dengan aksi tidur di jalanan untuk memblokade jalan eksekusi menuju objek sengketa, karena dianggap putusan inkracht tersebut tidak mencerminkan asas keadilan.

Sebagaimana dipahami dalam teori bekerjanya sistem hukum yang dikemukakan oleh Lawrence M. Friedman, bahwa bekerjanya sistem hukum dapat dilihat dari tiga komponen yaitu: komponen struktural, komponen kultural, dan komponen substantif. ${ }^{12}$

Komponen struktural pada putusan peradilan formal belum dapat dipenuhi karena seharusnya mengenai permasalahan sengketa pertanahan ini dapat dibentuk suatu pemisahan peradilan yang memungkinkan sengketa-sengketa mengenai pertanahan diadakan suatu peradilan khusus yang hakim-hakimnya betul-betul paham mengenai permasalahan pertanahan, mengingat banyak kasus pertanahan yang walaupun sudah dapat diselesaikan di peradilan umum dan sudah mendapatkan putusan inkracht, namun pada praktiknya belum dapat dieksekusi karena terdapat penolakan dari masyarakat.

Komponen kultural terdiri dari nilai-nilai dan sikap-sikap yang merupakan pengikat dari sistem hukum serta menentukan tempat sistem hukum ditengah kultur bangsa. Seperti yang tercantum dalam Pasal 5 ayat (1) UU No. 48 Tahun 2009 tentang Kekuasaan Kehakiman yang menuliskan bahwa "Hakim dan hakim konstitusi wajib menggali, mengikuti, dan memahami nilai-nilai hukum dan rasa keadilan yang hidup dalam masyarakat". Sudikno Mertokusumo juga menambahkan bahwa sumber-sumber untuk menemukan hukum bagi hakim dapat berasal dari perundang-undangan, hukum tidak tertulis, doktrin para ahli

\footnotetext{
${ }^{12}$ Satjipto Rahardjo, Hukum dan Masyarakat,(Bandung: Angkasa, 1980), halaman 19.
} 
hukum, dan yurisprudensi. Pemberian putusan juga seharusnya berdasarkan kenyataan sosial yang hidup dalam masyarakat, hakim dapat meminta keterangan dari para ahli, ketua adat, dan sebagainya. ${ }^{13}$ Komponen ini belum dipenuhi karena belum digunakannya nilainilai dari Masyarakat AKUR sebagai pengisi kekurangan-kekurangan yang dibutuhkan untuk menjelaskan penggunaan dari sistem hukum.

Komponen substantif ini merupakan penggunaan norma-norma berupa peraturanperaturan, doktrin-doktrin, kebiasaan-kebiasaan, atau keputusan-keputusan yang digunakan dalam masyarakat, meskipun kebiasaan-kebiasaan tersebut belum mendapatkan pengakuan secara formal, namun harus dipastikan digunakan dalam masyarakat. Diatur pula pada Pasal 50 ayat (1) UU Kekuasaan Kehakiman bahwa "Putusan pengadilan selain harus memuat alasan dan dasar putusan harus memuat pasal tertentu dari peraturan perundang-undangan yang bersangkutan dan juga sumber hukum tidak tertulis yang dijadikan dasar untuk mengadili". Komponen ini baru digunakan sebagian karena hakim baru menerapkan penggunaan peraturan-peraturan tertulis tetapi belum menggunakan sumber hukum lain yang tidak tertulis seperti kebiasaan-kebiasaan Masyarakat AKUR dan hukum adat mereka.

Ketiga komponen ini berada dalam proses interaksi satu sama lain dengan demikian membentuk totalitas yang dinamakan sistem hukum. ${ }^{14}$ Maka dari itu sistem hukum belum dapat dikatakan berjalan sebagaimana mestinya, sehingga belum tercapai asas keadilan bagi Masyarakat AKUR.

Bagi Masyarakat AKUR tanah di lingkungan adat mereka adalah milik bersama dan tidak dapat dibagi wariskan, hal ini sesuai dengan pesan atau amanat dari Pangeran Madrais. Tanah yang mereka miliki digunakan untuk kepentingan bersama, bahkan Paseban Tri Panca Tunggal yang biasanya menjadi tempat ibadah, berkumpul, dan pusat kegiatan Masyarakat AKUR tidak hanya milik Masyarakat AKUR semata tetapi siapa saja yang membutuhkan dapat menggunakannya, tentunya dengan seizin Masyarakat AKUR. Sedangkan pengelolaan dan pengurusannya saja yang diserahkan kepada keluarga keturunan Pangeran Madrais.

Aset-aset Masyarakat AKUR bersifat komunal, yang mereka dasarkan pada rapat bersama Pupuhu Adat dan Ais Pangampih untuk mencatatkan atas nama Pupuhu Adat.

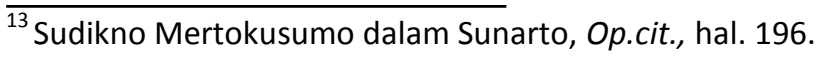

${ }^{14}$ Satjipto Rahardjo, Op.cit., hal. 86.
} 
Vol 2, No. (2019): Law, Development \& Justice Review, Mei 2019. e-ISSN: 2655-1942

Oleh karena itu tanah tersebut dapat dibagi wariskan. Perundang-undangan menamakan hak semacam ini dengan nama hak ulayat.

Saat ini memang ada pengaturan yang memungkinkan pencatatan tanah sebagai hak ulayat atau hak komunal. Pengaturan ini diatur pada Pasal 5 Peraturan Menteri Agraria dan Tata Ruang No.10 Tahun 2016 tentang Tata Cara Penetapan Hak Komunal atas Tanah Masyarakat Hukum Adat dan Masyarakat yang Berada dalam Kawasan Tertentu. Syarat mengenai pendirian koperasi atau kelompok masyarakat yang kemudian tidak dapat dipenuhi oleh Masyarakat AKUR, karena Masyarakat AKUR bukanlah sebuah organisasi. Masyarakat Hukum Adat tidak bisa disamakan dengan organisasi karena memang walaupun memiliki AD/ART yang dapat dikatakan setara dengan pendirian suatu organisasi, namun bukan itu yang menjadi dasar mereka melainkan hukum adat.

Terdapat tiga alasan yang mendasari Masyarakat AKUR mempertahankan objek sengketa yaitu alasan filosofis, historis dan alasan sosial budaya.

Alasan filosofis Masyarakat AKUR mempertahankan objek sengketa dapat dilihat dari aksi yang dilakukan guna menghalangi eksekusi yaitu bertujuan untuk menunjukkan kepada negara bahwa secara de facto bahwa Masyarakat AKUR memang sebuah komunitas yang harus dilihat eksistensinya dan negara mengakuinya.

Alasan historis yang menjadi dasar mempertahankan objek sengketa bagi Masyarakat AKUR adalah karena adanya manuskrip yang ditulis oleh Pangeran Madrais. sebagai pedoman dalam berkehidupan.

Alasan sosial budaya dapat dilihat dari tidak adanya keserasian dalam masyarakat (social equilibrium). Ketidakserasian ini disebabkan karena putusan peradilan umum yang memenangkan Penggugat tersebut, bertentangan dengan ketentuan adat yang dipatuhi oleh Masyarakat AKUR. Hal ini kemudian mempengaruhi psikologis masyarakat karena tidak adanya ketentraman, sehingga mereka melakukan aksi penolakan tersebut.

\section{SIMPULAN DAN SARAN}

1. Dasar pertimbangan hukum bagi hakim dalam memutuskan sengketa tanah Masyarakat AKUR adalah, Hakim menganggap bahwa objek sengketa adalah objek waris dan Hakim tidak mempertimbangkan keterangan saksi hidup yang tidak disumpah. Hakim menganggap objek sengketa sebagai harta warisan karena didasari adanya Surat Letter C No. C. 2321 Persil 78a Kelas D.1 tertangggal 20 November 2008. Hakim tidak 
Vol 2, No. (2019): Law, Development \& Justice Review, Mei 2019. e-ISSN: 2655-1942

mempertimbangkan keterangan saksi, karena kolom agama di KTP kosong, jadi tidak dapat diambil sumpahnya.

2. Pertimbangan hakim didasarkan pendekatan atau paradigma Positivisme, karena hanya dilandasi aturan tertulis dalam perundang-undangan dan belum dapat melihat nilai-nilai yang hidup dalam masyarakat.

3. Putusan peradilan umum terhadap sengketa tanah Masyarakat AKUR tidak mencerminkan asas keadilan karena belum mencapai tiga komponen, yaitu: komponen struktural, komponen kultural, dan komponen substantif. Komponen struktural belum dipenuhi karena belum ada pemisahan untuk sengketa pertanahan di lembaga peradilan umum. Komponen kultural belum dipenuhi karena tidak mendasari pada nilainilai yang hidup pada Masyarakat AKUR. Komponen substantif belum dipenuhi karena hanya melihat dari apa yang tertera dalam peraturan perundang-undangan tidak melihat adanya sumber hukum lain yang tidak tertulis, yaitu hukum adat setempat. Masyarakat AKUR tetap mempertahankan tanah yang menjadi objek sengketa dikarenakan adanya alasan filosofis, historis, dan sosial budaya. Alasan filosofisnya dapat dilihat dari aksi penolakan objek sengketa, yang ingin menunjukkan eksistensi masyarakat hukum adat. Alasan historisnya karena adanya ketentuan bahwa tanah yang menjadi aset Masyarakat AKUR di Desa Cigugur tidak dapat dibagi wariskan dan harus dipergunakan untuk kepentingan bersama, termasuk kedalamnya adalah objek sengketa. Alasan sosial budayanya karena terdapat pertentangan antara putusan lembaga peradilan umum dengan nilai-nilai Masyarakat AKUR sehingga menimbulkan rasa ketidaktentraman.

\section{DAFTAR PUSTAKA}

Berdayakan Masyarakat Adat, Lindungi Hak-haknya. Oktober-Desember 2017. Buletin, Gaung AMAN: Suara Masyarakat Adat.

Djais, Mohammad dan Koosmargono. 2011. Membaca dan Mengerti HIR. Semarang: Badan Penerbit Universitas Diponegoro.

Gamin dan Fati Lazira. Juli 2017. Penyelesaian Sengketa Ruang Hidup Masyarakat Sunda Wiwitan di Kabupaten Kuningan. Jurnal Sosiologi Pendidikan Humanis Vol.2 No.1. 
Vol 2, No. (2019): Law, Development \& Justice Review, Mei 2019. e-ISSN: 2655-1942

Indarti, Erlyn. 2010. Diskresi dan Paradigma Sebuah Telaah Filsafat Hukum. Pidato pengukuhan disampaikan pada upacara penerimaan jabatan Guru Besar dalam Filsafat Hukum pada Fakultas Hukum Universitas Diponegoro tanggal 4

Muttaqien, Ahmad. Januari-Juni 2013. Spiritualitas Agama Lokal (Studi Ajaran Sunda Wiwitan aliran Madrais di Cigugur, Kuningan, Jawa Barat). Jurnal Al-Adyan Vol.VIII No.1 .

November 2010.

Peraturan Menteri Agraria dan Tata Ruang No.10 Tahun 2016 tentang Tata Cara Penetapan

Hak Komunal atas Tanah Masyarakat Hukum Adat dan Masyarakat yang Berada dalam Kawasan Tertentu.

Prasetyo, Agung Basuki. Juni 2010. Hak Ulayat Sebagai Hak Konstitusional (Suatu Kajian Yuridis Empiris). Jurnal MMH Jilid 39 No.2.

Putusan Mahkamah Agung Nomor 2394k/Pdt/2010

Putusan Pengadian Tinggi Bandung Nomor 82/Pdt/2010/PT.Bdg

Putusan Pengadilan Negeri Kuningan No. 7/Pdt.G/2009/Pn.Kng

Putusan Peninjauan Kembali Nomor 21PK/Pdt/2014

Rahardjo, Satjipto. 1980. Hukum dan Masyarakat. Bandung: Angkasa.

Rejeki, Roro Sri. Maret 2017. Agama Djawa Sunda (ADS). Religious: Jurnal Agama dan Lintas Budaya.

Soekanto, Soerjono dan Budi Sulistyowati. 2014. Sosiologi sebagai Suatu Pengantar. Jakarta: Raja Grafindo Persada.

Sukirno. 2018. Politik Pengakuan Hak Ulayat, Jakarta: Prenadamedia Group.

Sunarto. 2014. Peran Aktif Hakim dalam Perkara Perdata. Jakarta: Prenadamedia Grup. Undang-undang No. 5 Tahun 1960 tentang Peraturan Dasar Pokok-pokok Agraria 